\title{
GOOD CORPORATE GOVERNANCE DAN DAMPAKNYA TERHADAP KINERJA BERDASARKAN BALANCED SCORECARD
}

\author{
Dewi Fitriyani, Wiwik Tiswiyanti, Eko Prasetyo \\ Fakultas Ekonomi dan Bisnis Universitas Jambi \\ Email: dewi_fitriyani@unja.ac.id
}

\begin{abstract}
The aims of the study were to describe the practice of good corporate governance, to measure performance on PDAM with balanced scorecard, and to find out the correlation between the practice of good corporate governance to performance. This study conducted on five PDAM in Jambi Province. Collection of data obtained through interviews, questionnare, annual report, related of documents and policies. The results of this study indicate good corporate governance practices on PDAM in Jambi Province in pretty good kriteria. PDAM performance scores as measured by balanced scorecard show overall is still considered less than the target maksimum working. The result of Pearson Product Moment test show the correlation between good corporate governance practices with the performance has a strong relationship but not significant.
\end{abstract}

Keywords: Good Corporate Governance Practice, Performance, Balanced Scorecard.

\begin{abstract}
Abstrak: Penelitian ini bertujuan untuk mendeskripsikan praktik good corporate governance, mengukur kinerja kinerja pada Perusahaan Daerah Air Minum (PDAM) dengan balanced scorecard dan untuk mengetahui korelasi antara praktik good corporate governance terhadap kinerja. Studi ini dilakukan di lima PDAM di Provinsi Jambi. Pengumpulan data diperoleh melalui wawancara, kuesioner, laporan tahunan, serta dokumen dan kebijakan yang terkait. Hasil studi mengindikasikan praktik good corporate governancepada PDAM di Provinsi Jambi memiliki kriteria cukup baik. Skor kinerja PDAM yang diukur dengan balanced scorecard menunjukkan secara keseluruhan kinerja PDAM masih dikategorikan kurang dari target kinerja maksimal. Hasil uji Pearson Product Moment menunjukkan korelasi antara praktik good corporate governance dengan kinerja memiliki hubungan yang kuat namun tidak signifikan.
\end{abstract}

Kata Kunci: Good Corporate Governance, Kinerja, Balanced Scorecard

\section{PENDAHULUAN}

Dewasa ini banyak pihak yang berpikir bahwa penerapan tata kelola perusahaan yang baik (good corporate governance) menjadi suatu kebutuhan sebagai barometer akuntabilitas dari suatu perusahaan. Lemahnya penerapan corporate governance sering diduga sebagai salah satu pemicu terjadinya berbagai skandal keuangan pada bisnis perusahaan. Good governance merupakan suatu paradigma dan perlu menjadi ciri dalam suatu administrasi suatu entitas. Menurut Sedarmayanti (2007), governance mencakup 3 (tiga) domain yaitu state (negara/pemerintahan), private sectors (sektor swasta/dunia usaha), dan society (masyarakat). Tata kelola di suatu entitas bisnis atau dunia usaha dikenal dengan good corporate governance. 
Dewasa ini banyak pihak yang mulai berpikir bahwa penerapan tata kelola perusahaan yang baik (good corporate governance) menjadi suatu kebutuhan sebagai barometer akuntabilitas dari suatu perusahaan.Lemahnya penerapan corporate governance diduga sebagai salah satu pemicu terjadi berbagai skandal keuangan pada bisnis perusahaan. Penerapan good corporate governance dinilai dapat memperbaiki citra perusahaan yang buruk, melindungi stakeholders serta meningkatkan kepatuhan terhadap peraturan perundang-undangan yang berlaku dan etika-etika umum pada dunia bisnis.

Pada dasarnya isu tentang corporate governance dilatarbelakangi oleh masalah keagenan.Menurut agency theory (Jensen and Meckling, 1976) permasalahan keagenan muncul karena pengelolaan perusahaan yang terpisah dengan pemiliknya.Pemilik (principal) sebagai pemasok modal perusahaan mendelegasikan wewenangnya atas pengelolaan perusahaannya kepada manajer profesional (agent) sehingga kewenangan untuk menggunakan sumber daya perusahaan ada pada tangan manajer.Hal itu dapat menimbulkan kemungkinan terjadinya moral hazard akibat adanya perbedaan kepentingan antara pemilik dan manajer.Manajer dengan informasi yang dimilikinya bisa bertindak untuk kepentingan pribadinya dengan mengorbankan kepentingan pemilik karena manajer memiliki informasi yang tidak dimiliki pemilik.Oleh karena itu diperlukan corporate governance untuk mengurangi permasalahan keagenan antara pemilik dan manajer.

Corporate governance merupakan seperangkat aturan dan prosedur yang menjamin manajer untuk menerapkan prinsip manajemen yangberetika. Cadbury Committeeyang dikutip Forum for Corporate Governance in Indonesia (FCGI) mendefinisikan good corporate governance sebagai seperangkat peraturan yang mengatur hubungan antara pemegang saham, pengurus (pengelola) perusahaan, pihak kreditur, pemerintah, karyawan serta para pemegang kepentingan intern dan ekstern lainnya yang berkaitan dengan hakhak dan kewajiban mereka, atau dengan kata lain suatu sistem yang mengatur dan mengendalikan perusahaan. Sedarmayanti (2007) menyatakan corporate governance adalah sistem, proses dan seperangkat peraturan yang mengatur hubugan antara berbagai pihak yang berkepentingan terutama dalam arti sempit, hubungan antara pemegang saham, dewan komisaris, dan dewan direksi demi tercapainya tujuan organisasi.

Pemerintah sangat mendukung adanya sistem tata kelola yang baik terutama pada entitas usaha yang dimilikinya baik yang dimiliki negara (BUMN) maupun daerah (BUMD). Pemerintah dalam hal ini Menteri Badan Usaha Milik Negara (BUMN) dalam Peraturan Menteri Nomor Per-01/MBU/2011 tentang Penerapan Tata Kelola Perusahaan yang Baik (Good Corporate Governance) pada Badan Usaha Milik Negara mendefinisikan good corporate governance adalah prinsip-prinsip yang mendasari suatu proses dan mekanisme pengelolaan perusahaan berlandaskan peraturan perundangundangan dan etika berusaha.

Perusahaan Daerah Air Minum (PDAM) merupakan Badan Usaha Milik Daerah (BUMD) yang dimiliki oleh Pemerintah Daerah Kota/Kabupaten sebagai pemasok modal.Adanya pemisahan pengelolaan perusahaan antara pemerintah dengan manajer yang mengelola dapat menjadikan adanya potensi masalah keagenan pada PDAM.Seperti halnya BUMN, pada dasarnya BUMD pun harus menerapkan good corporate governance. Praktik good corporate governancedapat menjamin dan melindungi para stakeholders dari kepentingan pribadi manajer. Nuswandari (2009) menyatakan bahwa corporate governance menciptakan mekanisme dan alat kontrol untuk memungkinkan terciptanya sistem pembagian keuntungan dan kekayaan yang seimbang bagi stakeholder dan menciptakan efisiensi bagi perusahaan. 
Good corporate governance (GCG) merupakan praktik terbaik yang biasa dilakukan oleh suatu perusahaan yang berhasil yang mengacu pada bauran antara alat, mekanisme, dan struktur yang menyediakan kontrol dan akuntabilitas yang dapat meningkatkan kinerja perusahaan. Praktik terbaik ini mencakup praktik bisnis, aturan main, struktur proses, dan prinsip yang dimiliki. Perusahaan dengan praktik GCG yang baik akan dapat meningkatkan nilai perusahaan bagi pemegang saham karena visi, misi dan strategi perusahaan dinyatakan dengan jelas, nilai-nilai perusahaan serta kode etik disusun untuk memastikan adanya kepatuhan seluruh jajaran perusahaan, terdapat kebijakan untuk menghindari benturan kepentingan dan transaksi dengan pihak ketiga yang tidak tepat, risiko perusahaan dikelola dengan baik dan terdapat sistem pengendalian dan monitoring yang baik.

Penelitian mengenai hubungan good corporate governance dan kinerja perusahaan telah banyak dilakukan.Mitton (2000) menunjukkan bahwa variabel-variabel yang berkaitan dengan corporate governance mempunyai dampak terhadap kinerja perusahaan selama periode krisis di Asia Timur. SelanjutnyaKlapper dan Love (2002) menemukan adanya hubungan positif antara corporate governance dengan kinerja perusahaan yang diukur dengan return on assets (ROA) dan Tobin's Q.Di Indonesia, Darmawati, dkk (2005) dapat membuktikan adanya hubungan antara corporate governance yang diukur dengan Corporate Governance Perception Index (CGPI) terhadap kinerja perusahaan yang diukur dengan return on equity (ROE). Selanjutnya, Wardhani (2008) menunjukkan adanya pengaruh corporate governance yang diukur dengan indeks corporate governance yang dikembangkan IICG terhadap kinerja perusahaan yang diukur dengan ROE dan Tobin's Q. Berikutnya Nuswandari (2009) dapat menemukan adanya pengaruh corporate governance yang diproksikan dengan CGPI terhadap kinerja operasional yang diukur dengan ROE, namun tidak ada pengaruh terhadap kinerja pasar yang diukur dengan Tobin's Q. Haryani, dkk (2011) menemukan bahwa kinerja perusahaan yang diukur oleh Tobin's Q dipengaruhi oleh variabel-variabel corporate governance.Masih kurangnya ditemukan studi mengenai good corporate governance terhadap badan usaha milik daerah (BUMD), maka penelitian ini mengetahui praktik good corporate governance pada kinerja PDAM yang tidak hanya diukur dari segi keuangan saja namun juga non keuangan. Untuk itu penelitian ini mengukur kinerja PDAM berdasarkan balanced scorecard.

Pada umumnya badan usaha swasta bertujuan untuk memperoleh laba semaksimal mungkin bagi kepentingan para pemiliknya.Namun pada sektor publik, selain kegiatan pelayanan yang bersifat bisnis juga memberikan pelayanan kepada masyarakat sehingga motif mencari laba menjadi tidak relevan untuk kegiatan-kegiatan dan operasi-operasi di sektor publik.Seperti yang dikemukakan Cahyono (2000), secara mendasarnya, organisasi sektor publik amat berbeda dengan organisasi swasta. Target utama perusahaan swasta adalah laba dan eksploitasi sumber daya secara maksimal, sedangkan organisasi sektor publik bertugas untuk menyediakan pelayanan publik dan mendistribusikan kesejahteraan dalam berbagai konteks target sosial dan ekonomi.

Demikian halnya pada Perusahaan Daerah Air Minum (PDAM) yang merupakan Badan Usaha Milik Daerah (BUMD).Meskipun dalam operasinya bertujuan mencari keuntungan namun juga memberikan pelayanan kepada masyarakat berupa air bersih.Untuk itu, pengukuran kinerja yang hanya berdasarkan segi keuangan seperti jumlah laba yang diperoleh tidaklah begitu cocok. Oleh karena itu untuk menilai kinerja organisasi sektor publik diperlukan banyak pendekatan selain pendekatan keuangan yaitu pendekatan nonkeuangan yang dapat diterapkan diorganisasi seperti balanced scorecard 
sebagai ukuran kinerja. Pengukuran kinerja berdasarkan balanced scorecard dimungkinkan untuk dapat diterapkan pada badan usaha di sektor publik karena mengandung empat perspektif, yaitu finansial, pelanggan, proses bisnis internal dan pembelajaran dan pertumbuhan. Selama ini PDAM mengukur kinerjanya berdasarkan Keputusan Menteri Dalam Negeri (Kepmendagri) Nomor 47 Tahun 1999 tentang Pedoman Penilaian Kinerja Perusahaan Daerah Air Minum yang menitikberatkan pada aspek keuangan, operasional dan administrasi.

Penelitian ini akan menguji dampak praktik good corporate governance terhadap kinerja. Berbeda dengan penelitian-penelitian sebelumnya yang mengukur praktik good corporate governance berdasarkan indeks CGPI, penelitian ini akan melihat praktik good corporate governance berdasarkan Peraturan Menteri Nomor Per-01/MBU/2011 tentang Penerapan Tata Kelola Perusahaan yang Baik (Good Corporate Governance) pada Badan Usaha Milik Negara. Peraturan ini digunakan dikarenakan PDAM memiliki karakteristik kepemilikan modal yang sama yaitu pemerintah. Negara yang diwakili oleh Pemerintah Republik Indonesia merupakan pemilik modal utama dari BUMN, sedangkan kepemilikan modal BUMD diperoleh dari pemerintah daerah. Perbedaan berikutnya adalah penelitian sebelumnya mengukur kinerja cenderung hanya menggunakan ukuran kinerja keuangan saja, penelitian ini akan menggunakan pengukuran kinerja berdasarkan empat perspektif balanced scorecard. Balanced scorecard merupakan perangkat pengukuran kinerja yang tidak hanya memandang dari perspektif keuangan (finansial) saja namun juga dari segi pelanggan, proses bisnis internal, dan proses pembelajaran dan pertumbuhan. Permasalahan pada penelitian ini adalahbagaimana hubungan antara good corporate governance terhadap kinerja yang diukur dengan balanced scorecard. Oleh karena itu berdasarkan permasalahan tersebut maka penelitian ini bertujuan untuk mengetahui hubungan good corporate governance terhadap kinerja yang diukur dengan balanced scorecard.

\section{KAJIAN TEORI}

Agency Theory dan Good Corporate Governance. Perspektif hubungan keagenan merupakan dasar yang digunakan untuk memahami hubungan antara manajer dan pemilik modal. Jensen dan Meckling (1976) mendefinisikan hubungan keagenan sebuah kontrak antara satu pihak yaitu prinsipal dalam hal ini pihak pemegang saham yang mempekerjakan pihak lain yaitu agen atau manajemen perusahaan untuk mengerjakan sesuatu atas nama prinsipal. Agency theory memiliki asumsi bahwa tiap individu termotivasi oleh kepentingan dirinya sendiri sehingga menimbulkan konflik kepentingan antara prinsipal dan agen.Dengan demikian terdapat alasan yang kuat untuk meyakini bahwa agen tidak selalu bertindak yang terbaik untuk kepentingan prinsipal.

Sulitnya memonitor atau kurang transparannya proses pengambilan keputusan oleh agen menyebabkan prinsipal tidak mempunyai informasi yang cukup mengenai kinerja agen. Agen mempunyai lebih banyak informasi mengenai lingkungan kerja dan kondisi perusahaan secara keseluruhan.Hal inilah yang menyebabkan ketidakseimbangan informasi yang dimiliki oleh prinsipal dan agen yang sering disebut dengan asimetri informasi.

Praktik corporate governance mengurangi permasalahan keagenan antara pemilik dan manajer.Praktik corporate governance yang baik dapat membantu menghindari benturan kepentingan antara prinsipal dan agen. Perusahaan yang menerapkan good 
corporate governance dengan baik akan dapat meningkatkan nilai perusahaan yang pada akhirnya dapat memperbaiki kinerja perusahaan.

Cadburry Committee menyatakan good corporate governance sebagai berikut:

" $a$ set of rules that define the relationship between shareholders, manager, creditors, the government, employees and other internal and external shareholders in respect to their rights and responsibilities, or the system by which companies are directed and controlled assessment"

Menurut Komite Nasional Kebijakan Corporate Governance (KNKCG) yang kemudian, corporate governance adalah suatu proses dan struktur yang digunakan oleh organ perusahaan guna memberikan nilai tambah pada perusahaan secara berkesinambungan dalam jangka panjang bagi pemegang saham, dengan tetap memperhatikan kepentingan stakeholder lainnya berlandaskan peraturan perundangan dan norma yang berlaku. Peraturan Menteri BUMN Nomor Per-01/MBU/2011 mendefinisikan good corporate governance adalah prinsip-prinsip yang mendasari suatu proses dan mekanisme pengelolaan perusahaan berlandaskan peraturan perundang-undangan dan etika berusaha. Penerapan corporate governance yang baik dapat menjamin transparansi, akuntabilitas, independensi, dan keadilan. Berikut prinsip-prinsip good corporate governance berdasarkan Peraturan Menteri BUMN Nomor Per-01/MBU/2011: (1) Transparansi (transparency), yaitu keterbukaan dalam melaksanakan proses pengambilan keputusan dan keterbukaan dalam mengungkapkan informasi material dan relevan mengenai perusahaan; (2) Akuntabilitas (accountability), yaitu kejelasan fungsi, pelaksanaan dan pertanggungjawaban organ sehingga pengelolaan perusahaan terlaksana secara efektif; (3) Pertanggungjawaban (responsibility), yaitu kesesuaian di dalam pengelolaan perusahaan terhadap peraturan perundang-undangan dan prinsip-prinsip korporasi yang sehat; (4) Kemandirian (independency), yaitu keadaan di mana perusahaan dikelola secara professional tanpa benturan kepentingan dan pengaruh/tekanan dari pihak manapun yang tidak sesuai dengan peraturan perundang-undangan dan prinsip-prinsip korporasi yang sehat; (5) Kewajaran (fairness), yaitu keadilan dan kesetaraan di dalam memenuhi hak-hak pemangku kepentingan (stakeholders) yang timbul berdasarkan perjanjian dan peraturan perundang-undangan.

KNKCGmerumuskan prinsip-prinsip good corporate governancesebagai berikut: (1) Hak-hak pemegang saham dan prosedur RUPS; (2) Komisaris; (3) Direksi; (4) Sistem Audit; (5) Sekretaris Perusahaan; (6) Pihak-pihak yang berkepentingan; (7) Keterbukaan; (8) Kerahasiaan; (9) Informasi Orang Dalam; (10) Etika Berusaha dan Anti Korupsi; (11) Donasi; (12) Kepatuhan pada perundang-undangan tentang proteksi kesehatan, keselamatan kerja dan pelestarian lingkungan; (13) Kesempatan kerja sama.

Menurut Forum Corporate Governance in Indonesia (FCGI) adabeberapa manfaat dari penerapan good corporate governanceyang baik, antaralain: (1) Meningkatkan kinerja perusahaan; (2) Mempermudah diperolehnya dana pembiayaan yang lebih murah yang padaakhirnya akan meningkatkan corporate value; (3) Mengembalikan kepercayaan investor untuk kembali menanamkan modalnyadi Indonesia; (4) Pemegang saham akan merasa puas dengan kinerja perusahaan karena sekaligus akan meningkatkan Shareholders's value dan deviden

Menurut Bassel Committee on Banking Supervision, tujuan dan manfaat goodcorporate governance antara lain sebagai berikut: (1) Mengurangi agency cost, biaya yang timbul karena penyalahgunaanwewenang, ataupun berupa biaya pengawasan yang timbul untuk mencegahtimbulnya suatu masalah; (2) Mengurangi biaya modal yang timbul dari 
manajemen yang baik, yangmampu meminimalisir resiko; (3) Memaksimalkan nilai saham perusahaan, sehingga dapat meningkatkan citra perusahaan dimata publik dalam jangka panjang; (4) Mendorong pengelolaan perbankan secara profesional, transparan, efisienserta memberdayakan fungsi dan meningkatkan kemandirian dewankomisaris, direksi dan RUPS; (5) Mendorong dewan komisaris, anggota direksi, pemegang saham dalammembuat keputusan dan menjalankan tindakan dilandasi moral yang tinggidan kepatuhan terhadap perundang-undangan yang berlaku; (6) Menjaga going concern perusahaan.

Penilaian Kinerja. Perusahaan Daerah Air Minum (PDAM) merupakan bentuk perusahaan yang dimiliki oleh pemerintah daerah. Sebagai Badan Usaha Milik Daerah, PDAM merupakan bagian dari organisasi sektor publik. Menurut Mahsun (2009) organisasi sektor publik berhubungan langsung dengan penyediaan barang dan jasa untuk memenuhi keinginan dan kebutuhan masyarakat. Meskipun demikian organisasi sektor publik bukanlah hanya organisasi yang berorientasi non profit. Pada kenyataannya terdapat organisasi sektor publik yang berbentuk quasi non profit organisation. Quasi non profit organisation merupakan organisasi yang bertujuan untuk menyediakan atau menjual barang dan/atau jasa kepada masyarakat dan memperoleh keuntungan dari kegiatan tersebut. PDAM merupakan bentuk quasi non profit organisation yang menghasilkan quasi private goods (Mahsun, 2009). Mahsun menjelaskan bahwa quasi privat goods adalah barang-barang atau jasa kebutuhan masyarakat yang mana manfaat barang atau jasa tersebut hanya dinikmati secara individual oleh yang membelinya walaupun sebetulnya barang atau jasa tersebut dapat dinikmati oleh semua masyarakat.

Kinerja organisasi publik harus dilihat secara luas dengan mengidentifikasi keberhasilan organisasi tersebut dalam memenuhi kebutuhan masyarakat sehingga pendekatan dalam pengukuran kinerja harus juga berlandaskan kepuasan masyarakat. Menurut Helfert (1996), kinerja dapat didefinisikan sebagai suatu tampilan keadaan secara utuh atau prestasi yang dipengaruhi oleh kegiatan operasional perusahaan dalam memanfaatkan sumber-sumber daya yang dimiliki.

Balanced Scorecard. Balanced Scorecard (BSC) yang diperkenalkan pertama kali oleh Kaplan dan Norton adalah suatu perangkat pengukuran kinerja yang memberikan manajemen puncak suatu pandangan yang cepat dan komprehensif tentang perusahaan.Balanced scorecard adalah suatu teknik yang banyak digunakan untuk mengukur kinerja perusahaan (Rangkuti, 2014). Balanced scorecard mengukur kinerja perusahaan pada empat perspektif yang seimbang (balanced), yaitu finansial, keuangan, proses bisnis internal, dan proses pembelajaran dan pertumbuhan (Kaplan dan Norton, 2000).

Pada dasarnya, menurut Kaplan dan Norton (2000) perusahaan menggunakan fokus pengukuran scorecard untuk menghasilkan berbagai proses manajemen penting untuk: (1) memperjelas dan menerjemahkan visi dan strategi; (2) mengkomunikasikan dan mengaitkan berbagai tujuan dan ukuran strategis; (3) merencanakan, menetapkan sasaran, dan menyelaraskan berbagai inisiatif strategis; (4) meningkatkan umpan balik dan pembelajaran strategis

Balanced Scorecard memberi eksekutif kerangka kerja yang komprehensif untuk menerjemahkan visi dan strategi perusahaan ke dalam seperangkat ukuran yang terpadu.Balanced scorecard menerjemahkan misi dan strategi ke dalam berbagai tujuan 
dan ukuran yang tersusun ke dalam empat perspektif, yaitu finansial, pelanggan, proses bisnis internal, serta pembelajaran dan pertumbuhan.Empat perspektif scorecard memberi keseimbangan antara tujuan jangka pendek dan jangka panjang, antara hasil yang diinginkan dengan faktor pendorong tercapainya hasil tersebut, dan antara ukuran objektif yang keras dengan ukuran subjektif yang lebih lunak. Rangkuti (2014) menjelaskan bahwa perspektif keuangan (meningkatkan pendapatan, menurunkan biaya, serta memaksimalkan shareholder value) merupakan hasil dari tindakan sebagaimana ditunjukkan pada tiga perspektif tolok ukur operasional lainnya, yaitu: (1) Perspektif pelanggan (meningkatnya jumlah pelanggan baru, meningkatkan jumlah pelanggan loyal, serta meningkatnya kepuasan pelanggan). (2) Perspektif proses bisnis internal, yaitu kemampuan perusahaan untuk melakukan peningkatan secara terus-menerus melalui kegiatan proses produksi yang lebih baik, distribusi menjadi lebih cepat, cakupan hubungan masyarakat menjadi lebih luas, inovasi produksi menjadi lebih cepat, serta tanggung jawab sosial ke masyarakat menjadi lebih baik. (3) Perspektif pembelajaran dan pertumbuhan. Perspektif ini lebih banyak berfokus pada kegiatan sumber daya internal perusahaan seperti meningkatkan moral karyawan, meningkatkan kompensasi karyawan, serta mengembangkan sistem informasi yang sesuai dengan proses bisnis perusahaan.

Perspektif Finansial. Balanced scorecard menggunakan perspektif finansial karena ukuran finansial sangat penting dalam memberikan ringkasan atas konsekuensi tindakan ekonomis yang sudah diambil.Tujuan finansial berhubungan dengan profitabilitas, pertumbuhan penjualan yang cepat atau terciptanya arus kas.Dalam perspektif finansial memiliki 3 (tiga) aspek yang perlu diperhatikan, yaitu: (1) pertumbuhan pendapatan dan kombinasi pendapatan, (2) penurunan biaya dan peningkatan produktivitas, dan (3) penggunaan aset yang optimal dan strategi investasi.

Perspektif finansial diukur dengan rasio keuangan, yang terdiri dari rasio profitabilitas, rasio likuiditas, dan rasio aktivitas. Rasio profitabilitas merupakan rasio untuk mengukur kemampuan perusahaan dalam mengelola sumber daya untuk menghasilkan laba. Rasio likuiditas digunakan untuk mengukur kemampuan perusahaan dalam memenuhi kewajiban jangka pendeknya. Rasio solvabilitas untuk mengukur kemampuan perusahaan dalam memenuhi kewajiban jangka panjangnya. Rasio aktivitas adalah rasio untuk mengukur efektivitas perusahan dalam mengelola aset yang dimiliki.Pengukuran kinerja PDAM dapat menggunakan rasio keuangan berdasarkan Keputusan Menteri Dalam Negeri Nomor 47 Tahun 1999 tanggal 31 Mei 1999 tentang Pedoman Penilaian Kinerja PDAM yang terdiri dari 10 indikator, yaitu:rasio laba terhadap aset produktif, rasio laba terhadap penjualan, rasio aset lancar terhadap utang lancar, rasio utang jangka panjang terhadap ekuitas, rasio total aset terhadap total utang, rasio biaya operasi terhadap pendapatan operasi, rasio laba operasi sebelum biaya penyusutan terhadap angsuran pokok dan bunga jatuh tempo, rasio aset produktif terhadap penjualan air, jangka waktu penagihan piutang, dan efektivitas penagihan.

Perspektif Pelanggan. Dalam perspektif pelanggan, para manajer mengidentifikasi pelanggan dan segmen pasar tempat unit bisnis tersebut bersaing dan berbagai ukuran kinerja unit bisnis di dalam segmen sasaran.Ukuran utama dalam perspektif ini terdiri atas kepuasan pelanggan, retensi pelanggan, akuisisi pelanggan baru, profitabilitas pelanggan, pangsa pasar di segmen sasaran.Faktor pendorong keberhasilan pelanggan inti di segmen pasar tertentu merupakan faktor yang penting, yang dapat mempengaruhi keputusan 
pelanggan untuk berpindah atau tetap loyal kepada pemasoknya. Terdapat 5 (aspek) dalam perspektif pelanggan, yaitu (1) pengukuran pangsa pasar, (2) customer retention, (3) customer acquisition, (4) customer satisfaction, (5) customer profitabilty.

Perspektif Proses Bisnis Internal. Perspektif proses bisnis internal berfokus kepada berbagai proses internal yang berdampak pada kepuasan pelanggan dan pencapaian tujuan finansial perusahaan. Pada perspektif ini, balanced scorecard juga memasukkan berbagai proses inovasi.Proses bisnis internal merupakan kegiatan untuk menghasilkan produk atau jasa bagi pelanggannya (Rangkuti, 2014). Menurut Mahsun (2009) perspektif ini mencakup indikator produktivitas, kualitas, waktu penyerahan, waktu tunggu dan sebagainya. Kinerja pada perspektif proses bisnis internal diukur dengan menggunakan ukuran waktu proses, pengiriman tepat waktu dan efektivitas proses (Rangkuti, 2014).Menurut Rangkuti, proses internal bisnis dapat diukur melalui indikator inovasi produksi, proses operasi, dan layanan purna jual.

Perspektif Pembelajaran dan Pertumbuhan. Perspektif ini mengidentifikasi infrastruktur yang harus dibangun perusahaan dalam menciptakan pertumbuhan dan peningkatan kinerja jangka panjang.Terdapat tiga kategori utama pembelajaran dan pertumbuhan perusahaan, yaitu kapabilitas pekerja, kapabilitas sistem informasi, dan motivasi, pemberdayaan dan keselarasan.Dengan demikian perspektif iniakan mengukur faktor-faktor yang berhubungan dengan teknologi, pengembangan pegawai, sistemdan prosedur, dan faktor lain yang diperbaharui. Menurut Rangkuti (2014) kinerja pada perspektif pembelajaran dan pertumbuhan diukur dengan menggunakan ukuran tingkat keahlian, komitmen SDM dan suasana kerja. Rangkuti menyatakan ukuran dari perspektif pembelajaran dan pertumbuhan akan terlihat dari pencapaian peningkatan keahlian SDM, kemampuan sistem informasi, tingkat komitmen dan motivasi SDM. Selanjutnya Rangkuti menyatakan perspektif ini indikator yang diukur adalah produktivitas karyawan, retensi karyawan, kepuasan karyawan, serta kompetensi karyawan. Produktivitas karyawan merupakan kemampuan karyawan dalam menghasilkan laba bagi perusahaan. Semakin tinggi tingkat produktivitas karyawan, semakin tinggi output yang dihasilkan oleh karyawan. Retensi karyawan diukur oleh persentase perputaran karyawan. Pengukuran ini bertujuan untuk mempertahankan karyawan potensial yang dimiliki perusahaan agar tetap loyal kepada perusahaan. Kepuasan karyawan diukur menggunakan metode survei dengan menggunakan kuesioner.

Menurut Mulyadi (2007) perluasan perspektif rencana strategik dari yang sebelumnya hanya terbatas pada perspektif keuangan ke perspektif nonkeuangan menghasilkan manfaat sebagai berikut: (a) Menjanjikan kinerja keuangan yang berlipat ganda dan berkesinambungan karena dalam perencanaan, perhatian dan usaha personel difokuskan ke perspektif nonkeuangan-perspektif yang di dalamnya terletak pemacu sesungguhnya kinerja keuangan. (b) Memampukan perusahaan untuk memasuki lingkungan bisnis yang kompleks karena balanced scorecard menghasilkan rencana yang mencakup perspektif luas (keuangan, customer, proses, serta pembelajaran dan pertumbuhan), sehingga rencana yang dihasilkan mampu dengan kompleks merespon perubahan lingkungan.

Lebih lanjut Mulyadi menjelaskan kebutuhan perusahaan untuk mengimplementasikan balanced scorecard dipacu oleh faktor-faktor berikut ini: (1) Lingkungan bisnis yang dimasuki oleh perusahaan sangat kompetitif; (2) Sistem 
manajemen yang digunakan oleh perusahaan tidak pas dengan tuntutan lingkungan bisnis yang dimasuki oleh perusahaan; (3) Sistem pengelolaan kinerja personel tidak selaras dengan sistem manajemen strategik

Balanced Scorecard dinilai cocok untuk organisasi sektor publik karenatidak hanya menekankan pada aspek kuantitatif-finansial,tetapi juga aspek kualitatif dan nonfinansial.Hal tersebut sejalan dengan sektorpublik yang menempatkan laba bukan hanya sebagai ukuran kinerja utama, namun pelayanan yang cenderung bersifat kualitatif dan nonkeuangan (Mahmudi, 2007). Mahmudi (2007) juga menyatakan adanya fakta bahwa banyak perusahaan yang mengadopsi konsep balanced scorecard menunjukkan banyak perubahan yang signifikan, antara lain: manajemen semakin berorientasi pada pelanggan, waktu respon terhadap pelanggan semakin cepat, perbaikan kualitas produk, penekanan pada kerja tim, waktu untuk launching produk baru berkurang, dan manajemen lebih berorientasi pada masa depan.

Hipotesis. Mitton (2002) menunjukkan bahwa variabel-variabel yang berkaitan dengan corporate governance mempunyai dampak terhadap kinerja perusahaan selama periode krisis di Asia Timur. Selanjutnya Klapper dan Love (2002) menemukan adanya hubungan positif antara corporate governance dengan kinerja perusahaan yang diukur dengan return on assets (ROA) dan Tobin's Q.

Di Indonesia, Darmawati, dkk (2005) dapat membuktikan adanya hubungan antara corporate governance yang diukur dengan Corporate Governance Perception Index (CGPI) terhadap kinerja perusahaan pada perusahaan yang terdaftar di Bursa Efek Jakarta. Kinerja perusahaan dengan return on equity (ROE). Selanjutnya, Wardhani (2008) menunjukkan adanya pengaruh corporate governance yang diukur dengan indeks corporate governance yang dikembangkan IICG terhadap kinerja perusahaan yang terdaftar di Bursa Efek Indonesia yang mengalami permasalahan keuangan. Kinerja perusahaan diukur dengan ROE dan Tobin's Q. Berikutnya Nuswandari (2009) dapat menemukan adanya pengaruh corporate governance yang diproksikan dengan CGPI terhadap kinerja operasional yang diukur dengan ROE, namun tidak ada pengaruh terhadap kinerja pasar yang diukur dengan Tobin's Q. Haryani, dkk (2011) menemukan bahwa kinerja perusahaan yang diukur oleh Tobin's Q dipengaruhi oleh variabel-variabel corporate governance, yaitu komisaris independen, kepemilikan manajerial, dan auditor eksternal. Berdasarkan uraian teori dan penelitian terdahulu, penelitian ini menghipotesiskan:

Ha: Terdapat hubungan dan signifikan antara praktik good corporate governance terhadap kinerja PDAM di Provinsi Jambi

\section{METODE}

Objek Penelitian dan Subjek Penelitian. Objek penelitian ini adalahpraktik good corporate governance dan penilaian kinerja berdasarkan balance scorecard pada Perusahaan Daerah Air Minum (PDAM) di Provinsi Jambi.Penelitian dilakukan pada 5 (lima) PDAM, yaitu PDAM Tirta Mayang di Kota Jambi, PDAM Tirta Muaro Jambi di Kabupaten Muaro Jambi, PDAM Tirta Batanghari di Kabupaten Batanghari, PDAM Tirta Pangabuan di Kabupaten Tanjab Barat, dan PDAM Sako Batuah di Kabupaten Sarolangun. 


\section{Metode Pengumpulan Data}

Jenis data yang digunakan dalam penelitian ini adalah data primer dan data sekunder. Data primer dikumpulkan dengan metode wawancara dan survei dengan kuesioner terkait dengan praktik good corporate governance dan pengukuran kinerja berdasarkan perspektif balanced scorecard. Sedangkan data sekunder yang dibutuhkan berasal dari laporan keuangan yang telah diaudit KAP, laporan audit kinerja dari BPKP, struktur organisasi, dokumen dan kebijakan yang relevan dengan topik kajian.Semua data tersebut diperoleh dari masing-masing Perusahaan Daerah Air Minum (PDAM) di kabupaten/kota Provinsi Jambi.

Metode Analisis Data. Data dianalisis dengan menggunakan metode deskriptif kuantitatif.Metode ini digunakan pada Tahun Pertama untuk menganalisis praktik good corporate governance(GCG) pada setiap PDAM.Dari hasil analisis maka diperoleh deskripsi praktik good corporate governance pada PDAM.Data yang menjadi bahan analisis berasal dari struktur organisasi, tugas pokok dan fungsi dewan pengawas, laporan hasil audit kinerja BPKP, kebijakan perusahaan tentang good corporate governance yang dibandingkan dengan ketentuan Peraturan Menteri Negara BUMN Nomor Per01/MBU/2011 tentang Penerapan Tata KelolaPerusahaan yang Baik (Good Corporate Governance) pada Badan Usaha Milik Negara.Metode deskriptif kuantitatif juga digunakan untuk menganalisis pengukuran kinerja PDAM dengan menggunakan 4 (empat) perspektif dari balanced scorecard(BSC).

Populasi dan Sampel. Populasi dalam penelitian ini adalah seluruh pelanggan dan pegawai masing-masing PDAM. Populasi pelanggan digunakan untuk mengukur tingkat kepuasan pelanggan, sedangkan populasi pegawai untuk mengukur tingkat kepuasan pegawai. Berikut jumlah daftar jumlah populasi pelanggan masing-masing PDAM pada tahun 2013.

Tabel 1. Daftar Jumlah Populasi

\begin{tabular}{cccc}
\hline No & Nama PDAM & Jumlah Populasi Pelanggan & $\begin{array}{c}\text { Jumlah Populasi } \\
\text { Pegawai }\end{array}$ \\
\hline 1 & Tirta Mayang & 62.678 & 303 \\
2 & Tirta Muaro Jambi & 7.949 & 71 \\
3 & Tirta Batanghari & 5.231 & 49 \\
4 & Tirta Pangabuan & 3.436 & 42 \\
5 & Sako Batuah & 8.189 & 81 \\
\hline
\end{tabular}

Teknik pengambilan sampel dilakukan secara random sederhana. Jumlah sampel ditentukan dengan menggunakan rumus Slovin yaitu:

$$
\mathrm{n}=\frac{\mathrm{N}}{1+\mathrm{N} \cdot \mathrm{e}^{2}}
$$

keterangan: $\mathrm{n}=$ Jumlah sampel; $\mathrm{N}=$ Jumlah populasi; e = Persentasi error pengambilan sampel

Dalam menghitung jumlah sampel, penelitian ini menggunakan nilai error sebesar $10 \%$, sehingga diperoleh masing-masing sampel sebagai berikut: 
Fitriyani, Tiswiyanti dan Prasetyo: Good Corporate Governance dan Dampaknya...

Tabel 2. Daftar Jumlah Sampel

\begin{tabular}{llcc}
\hline No & \multicolumn{1}{c}{ Nama PDAM } & $\begin{array}{c}\text { Jumlah Sampel } \\
\text { Pelanggan }\end{array}$ & Jumlah Sampel Pegawai \\
\hline 1 & Tirta Mayang & 100 & 76 \\
2 & Tirta Muaro Jambi & 99 & 42 \\
3 & Tirta Batanghari & 99 & 33 \\
4 & Tirta Pangabuan & 98 & 30 \\
5 & Sako Batuah & 99 & 45 \\
\hline
\end{tabular}

Variabel Penelitian dan Pengukuran Variabel Penelitian. Good Corporate Governance(GCG). Praktik GCG dapat dilihat dengan pelaksanaan prinsip-prinsip GCG berdasarkan Peraturan Menteri BUMN Nomor Per-01/MBU/2011 tentang Penerapan Tata Kelola Perusahaan yang Baik (Good Corporate Governance) pada Badan Usaha Milik Negara.

Balanced Scorecard. Balanced scorecard diukur dengan empat perspektif balanced scorecard, yaitu perspektif finansial, perspektif pelanggan, perspektif proses bisnis internal dan proses pembelajaran dan pertumbuhan.

Pertama. Perspektif finansial. Perspektif ini diukur dengan tingkat pertumbuhan pendapatan, rasio profitabilitas, rasio solvabilitas, rasio likuiditas dan rasio aktivitas. Rasio profitabilitas menggunakan rasio laba terhadap penjualan (profit margin) dan rasio tingkat pengembalian investasi (return on investment). Rasio solvabilitas diukur dengan rasio utang terhadap aset (debt ratio), rasio utang terhadap modal (debt to equity ratio). Rasio likuiditas menggunakan rasio lancar (quick ratio), rasio aset lancar terhadap utang lancar (current ratio). Rasio aktivitas menggunakan ukuran periode penagihan rata-rata (collection days), dan rasio perputaran aset tetap (fixed assets turn over).

a. Tingkat pertumbuhan pendapatan.

Pendapatan $_{\mathrm{t}}-$ pendapatan $_{\mathrm{t}-1} \times 100 \%$

Pendapatan $_{\mathrm{t}}$

b. Rasio laba terhadap penjualan (profit margin)

Laba bersih $\quad x 100 \%$

Penjualan bersih

c. Rasio tingkat pengembalian modal (return on assets/ROA)

Laba bersih $\quad x 100 \%$

Total aset

d. Rasio utang terhadap modal (debt to equity ratio/DER)

Total utang $\quad \mathrm{x} 100 \%$

Total ekuitas

e. Rasio utang terhadap aset (debt ratio)

Total utang $\quad$ x $100 \%$

Total aset

f. Rasio cepat (quick ratio)

Total aset lancar - persediaan $\times 100 \%$

Total utang lancar

g. Rasio aset lancar terhadap utang lancar (current ratio)

Total aset lancar x 100\%

Total utang lancar 
h. Periode penagihan rata-rata (collection days)

Piutang usaha

Penjualan/365 hari

i. Perputaran aset tetap (fixed assets turnover)

Penjualan bersih

Aset tetap

Kedua. Perspektif pelanggan. Perspektif pelanggan diukur dengan kepuasan pelanggan, retensi pelanggan, akuisisi pelanggan baru, pangsa pasar di segmen sasaran, dan jumlah pelanggan yang tidak menjadi pelanggan lagi.

a. Kepuasan pelanggan diukur dengan menggunakan kuesioner yang diadopsi dari BPKP (2007) dan digunakan kembali oleh Prayogi (2011) dengan lima pilihan skala Likert yang diberi nilai 1 untuk sangat tidak setuju (STS), nilai 2 untuk tidak setuju (TS), nilai 3 untukragu-ragu (R), nilai 4 untuk setuju (S) dan nilai 5 untuk sangat setuju (SS).Kepuasan pelanggan dikatakan baik apabila mencapai nilai target skor. Target nilai skor adalah di atas 3 yang dianggap mencerminkan kepuasan pelanggan.

b. Akuisisi pelanggan.

Jumlah pelanggan baru $\times 100 \%$

Jumlah pelanggan

c. Profitabilitas pelanggan

Jumlah pendapatan usaha

Jumlah pelanggan

Ketiga. Perspektif Proses Bisnis Internal

a. Efisiensi produksi

Volume produksi riil (m3) $\times 100 \%$

Kapasitas terpasang (m3)

b. Tingkat kehilangan air

Distribusi air - air terjual $\times 100$

Distribusi air

Keempat. Perspektif Pembelajaran dan Pertumbuhan

a. Kepuasan karyawan (employee satisfaction)

Tingkat kepuasan karyawan diukur menggunakan kuesioner yang dikembangkan oleh BPKP (2007) dan digunakan kembali oleh Prayogi (2011). Skala Likert digunakan dalam kuesioner dengan 5 pilihan bobot skor, yaitu nilai 1 untuk sangat tidak setuju (STS), nilai 2 untuk tidak setuju (TS), nilai 3 untuk ragu-ragu (R), nilai 4 untuk setuju (S) dan nilai 5 untuk sangat setuju (SS). Kepuasan karyawan dikatakan bagus apabila mencapai nilai target skor. Target nilai skor adalah di atas 3 yang dianggap mencerminkan kepuasan karyawan.

b. Rasio biaya diklat Jumlah biaya pendidikan pegawa

Jumlah biaya pegawai

a. Produktivitas karyawan

$\underline{\text { Laba bersih }}$

Jumlah karyawan

Alat Analisis Data. Indeks Good Corporate Governance (GCG). Untuk membuat deskripsi pelaksanaan prinsip-prinsip GCG pada PDAM dilakukan dengan menganalisis hasil elemen indeks GCG berdasarkan Peraturan Menteri BUMN Nomor Per01/MBU/2011. Elemen-elemen dalam indeks tersebut diukur secara dikotomi (D) yaitu 
skor 1 (satu) jika ya dan skor 0 (nol) jika tidak dengan total maksimal persentase bobot skor adalah 100. Jumlah bobot skor dihitung dengan rumus:

$$
\mathrm{GCG}=\underline{\mathrm{n}} \times 100 \%
$$

Keterangan: $\mathrm{GCG}=$ indeks praktik good corporate governance $(\mathrm{GCG}) ; \mathrm{n}=$ jumlah elemen praktik GCG yang dilaksanakan; $\mathrm{k}=$ jumlah seluruh elemen praktik GCG yang mungkin dilaksanakan

Pengukuran berdasarkan Balanced Scorecard. Pada penelitian ini, ukuran kinerja PDAM berdasarkan balanced scorecard dilakukan dengan membuat skorberdasarkan penilaian empat perspektif balanced scorecard. Kinerja PDAM akan diukur rata-ratanya dan kemudian dibandingkan dengan target nilai skor. Berikut ini target kinerja masingmasing indikator perspektif dalambalanced scorecard.

Tabel 3. Target Nilai Kinerja Indikator

\begin{tabular}{lc}
\hline Perspektif & Target Kinerja \\
\hline Finansial: & \\
Pertumbuhan Pendapatan & $10 \%$ \\
Profit Margin & 0,10 \\
ROA & $10 \%$ \\
DER & $100 \%$ \\
Debt Ratio & $50 \%$ \\
Rasio Lancar & 0,70 \\
Rasio Cepat & 1,80 \\
Periode Penagihan & 37 \\
Perputaran Aset Tetap & 0,70 \\
Pelanggan: & \\
Akuisisi Pelanggan & $10 \%$ \\
Profitabilitas Pelanggan & 1.000 .000 \\
Kepuasan Pelanggan & 3 \\
Proses Bisnis Internal: & \\
Efisiensi Produksi & $90 \%$ \\
Tingkat Kehilangan Air & $20 \%$ \\
Pembelajaran dan Pertumbuhan: & \\
Rasio Biaya Diklat & $10 \%$ \\
Produktivitas pegawai & 10.000 .000 \\
Kepuasan pegawai & 3 \\
\hline
\end{tabular}

Komposisi penilaian balanced scorecard ditampilkan di bawah ini.

Tabel 4. Komposisi Penilaian Balanced Scorecard

\begin{tabular}{lcccc}
\hline \multicolumn{1}{c}{ Perspektif } & $\begin{array}{c}\text { Jumlah } \\
\text { Indikator }\end{array}$ & $\begin{array}{c}\text { Skor } \\
\text { Maks }\end{array}$ & $\begin{array}{c}\text { Bobot Skor } \\
\text { Indikator }\end{array}$ & $\begin{array}{c}\text { Jumlah Bobot } \\
\text { Skor Maks }\end{array}$ \\
\hline Finansial & 9 & 1 & 5 & 45 \\
Pelanggan & 3 & 1 & 10 & 30 \\
Proses Bisnis Internal & 2 & 1 & 5 & 10 \\
Pembelajaran dan Pertumbuhan & 3 & 1 & 5 & 15 \\
& TOTAL SKOR & & & 100 \\
\hline
\end{tabular}


Setelah menghitung komposisi penilaian masing-masing perspektif dalam balanced scorecard, kemudian dilakukan pengukuran nilai skor untuk setiap indikatoryang ditampilkan dalam tabel di bawah ini.

Tabel 5. Nilai Skor

\begin{tabular}{cc}
\hline Nilai Skor Indikator & Keterangan \\
\hline-1 & Di bawah target kinerja \\
0 & Sama dengan target kinerja \\
1 & Di atas target kinerja \\
\hline
\end{tabular}

Penentuan hasil akhir skor pada balanced scorecard dilakukan secara seimbang masingmasing perspektif. Kriteria keseimbangan digunakan untuk mengukur sejauhmana pencapaian sasaran strategik seimbang di semua perspektif (Mulyadi, 2001). Skor dalam tabel kriteria keseimbangan adalah skor standar jika kinerja semua aspek dalam perusahaan adalah baik dengan skala rating sebagai berikut:

Tabel 6. Skala Rating Skor

\begin{tabular}{ccl}
\hline Total Skor Kinerja & Nilai Kinerja & \\
\cline { 3 - 3 } Di bawah 50 & Kurang & Kinerja dibawah nilai skor maks \\
$51-79$ & Cukup & Kinerja mencapai nilai skor maks \\
$80-100$ & Baik & Kinerja diatas nilai skor maks \\
\hline
\end{tabular}

Uji Validitas dan Uji Reliabilitas. Uji validitas data mengukur skor masing-masing item dengan skor total.Pada penelitian ini uji validitas dilakukan dengan melakukan korelasi bivariate antara masing-masing skor indikator dengan total skor konstruk menggunakan SPSS 17. Berdasarkan hasil pengolahan SPSS diperoleh bahwa seluruh korelasi bivariate kuesionermemiliki tingkat signifikansi kurang dari $\alpha=0,05$ sehingga dapat dikatakan valid (data terlampir).

Pengujian uji reliabilitas akan menggunakan cronbach's alpha. Suatu kuesioner dapat dikatakan reliabel apabila nilai cronbach's alpha lebih besar dari 0,60 (Nunnaly, 1960 dalam Ghozali, 2011).Hasil uji reliabilitas menunjukkan kuesioner memiliki adalah reliabel ditunjukkan dengan nilai signifikansi < 0,05 (tabel 7).

Tabel 7. Hasil Uji Reliabilitas

\begin{tabular}{cccccc}
\hline $\begin{array}{c}\text { Nilai Cronbach's } \\
\text { Alpha }\end{array}$ & $\begin{array}{c}\text { Tirta Muaro } \\
\text { Jambi }\end{array}$ & $\begin{array}{c}\text { Tirta } \\
\text { Batanghari }\end{array}$ & $\begin{array}{c}\text { Tirta } \\
\text { Mayang }\end{array}$ & $\begin{array}{c}\text { Tirta } \\
\text { Pangabuan }\end{array}$ & $\begin{array}{c}\text { Sako } \\
\text { Batuah }\end{array}$ \\
\hline Pelanggan PDAM & 0,893 & 0,935 & 0,963 & 0,923 & 0,920 \\
Pegawai PDAM & 0,877 & 0,870 & 0,879 & 0,860 & 0,876 \\
\hline
\end{tabular}

Uji Normalitas Data. Normalitas data pada penelitian ini diuji menggunakan uji Kolmogorov-Smirnov. Data dikatakan berdistribusi normal apabila nilai asymp. Sig. lebih besar dari 0,05 pada alpha 0,05. Hasil ouput SPSS diperoleh nilai asymp. Sig lebih besar dari 0,05 sehingga data memiliki distribusi normal (Tabel 8). 
Tabel 8. Hasil Uji Normalitas

\begin{tabular}{cc}
\hline Keterangan & Nilai Asymp. Sign. \\
\hline Indeks GCG & 0,893 \\
Skor BSC & 0,877 \\
\hline
\end{tabular}

Uji Korelasi. Uji korelasi dilakukan untuk menguji hubungan antara praktik good corporate governance(GCG) terhadap kinerja PDAM yang diukur dengan balanced scorecard(BSC). Uji korelasi pada penelitian ini menggunakan korelasi Product Moment. Nilai koefisien korelasi berkisar -1 sampai +1 . Koefisien korelasi semakin kuat jika mendekati angka 1 dan semakin lemah jika koefisien korelasi mendekati angka 0 (Suliyanto, 2011).

\section{HASIL DAN PEMBAHASAN}

Praktik Good Corporate Governance(GCG) pada Perusahaan Daerah Air Minum (PDAM) diProvinsi Jambi. Penelitian ini dilakukan pada 5 (lima) PDAM, yaitu PDAM Tirta Mayang di Kota Jambi, PDAM Tirta Muaro Jambi di Kabupaten Muaro Jambi, PDAM Tirta Batanghari di Kabupaten Batanghari, PDAM Tirta Pangabuan di Kabupaten Tanjab Barat, dan PDAM Sako Batuah di Kabupaten Sarolangun. Indeks Praktik GCG yang diukur dengan bobot skor berdasarkan Peraturan Menteri BUMN Tahun 2011 tentang penerapan tata kelola perusahaan yang baik (good corporate governance) pada BUMN diperoleh hasil sebagai berikut.

Tabel 9. Hasil Bobot Skor Indeks Praktik GCG pada PDAM

\begin{tabular}{cccc}
\hline No & Nama PDAM & Bobot Skor & Kriteria \\
\hline 1 & PDAM Tirta Muaro Jambi & 65,71 & Cukup Baik \\
2 & PDAM Tirta Batanghari & 62,86 & Cukup Baik \\
3 & PDAM Tirta Mayang & 68,57 & Cukup Baik \\
4 & PDAM Tirta Pangabuan & 62,86 & Cukup Baik \\
5 & PDAM Sako Batuah & 62,86 & Cukup Baik \\
\hline
\end{tabular}

Berdasarkan hasil indeks praktik GCG pada tabel di atasdiketahui PDAM Tirta Mayang memiliki bobot skor paling tinggi yaitu 68,57. PDAM Tirta Mayang dibandingkan dengan PDAM yang lain, telah memiliki satuan pengawasan intern. Namun hanya PDAM Tirta Muaro Jambi yang dapat menunjukkan pedoman tata kelola perusahaannnya.

Sebagian besar PDAM tidak ada yang dapat menunjukkan pedoman manajemen risiko, pedoman etika berperilaku (code of conduct) dan pedoman tata kelola teknologi informasi. Perusahaan terlihat belum dapat menunjukkan adanya peraturan tertulis mengenai keselamatan kerja dan pelestarian lingkungan serta ketentuan etika berusahan, anti korupsi dan donasi.

PDAM dalam struktur organisasinya belum ada yang memiliki komite audit, namun berkaitan dengan keterbukaan informasi, PDAM memberikan akses informasi terhadap auditor. Sebagai Badan Usaha Milik Daerah (BUMD) yang modalnya berasal dari Pemerintah Daerah, PDAM diaudit oleh Kantor Akuntan Publik yang ditunjuk oleh BPK. Untuk audit kinerja, perusahaan diaudit oleh BPKP. Perusahaan memberikan keleluasan dan keterbukaan informasi yang dibutuhkan kepada para auditor. Informasi penting yang 
diperlukan dilaporkan perusahaan dalam laporan keuangan tahunan. Dalam hal penyusunan anggaran dan rencana kerja, perusahaan telah memiliki dan melaksanakan sesuai dengan ketentuan yang ada.

PDAM telah memiliki ketentuan yang mengatur mengenai kriteria, komposisi, hak dan tanggung jawab dewan pengawas, direktur dan juga organ lainnya dalam perusahaan.Perusahaan juga memiliki pola hubungan kerja antara dewan pengawas dengan direksi. Rapat dewan pengawas telah dilakukan secara berkala.

PDAM memberikan adanya kesempatan karir pada setiap karyawan dengan menjamin adanya kesempatan yang sama pada setiap pegawai tanpa melihat latar belakang seseorang. Perusahaan juga telah memuat aturan mengenai rangkap jabatan, benturan kepentingan dan larangan mengambil keuntungan pribadi yang tercantum dalam peraturan daerah tentang organisasi dan tata kerja PDAM.

Pengukuran Kinerja PDAM Berdasarkan Balanced Scorecard. Pengukuran kinerja berdasarkan balanced scorecard berdasarkan empat perspektif, yaitu perspektif finansial, perspektif pelanggan, perspektif proses bisnis internal, dan perspektif pembelajaran dan pertumbuhan. Berikut skor kinerja PDAM di Provinsi Jambi yang diukur berdasarkan balanced scorecard.

Tabel 10. Skor Kinerja PDAM di Provinsi Jambi berdasarkan Balanced Scorecard

\begin{tabular}{lccccc}
\hline Perspektif & $\begin{array}{l}\text { PDAM Tirta } \\
\text { Ma Jambi }\end{array}$ & $\begin{array}{l}\text { PDAM } \\
\text { Tirta } \\
\text { Batanghari }\end{array}$ & $\begin{array}{l}\text { PDAM } \\
\text { Tirta } \\
\text { Mayang }\end{array}$ & $\begin{array}{l}\text { PDAM } \\
\text { Tirta } \\
\text { Pangabuan }\end{array}$ & $\begin{array}{l}\text { PDAM } \\
\text { Sako } \\
\text { Batuah }\end{array}$ \\
\hline $\begin{array}{l}\text { Finansial } \\
\text { Pelanggan }\end{array}$ & -5 & -5 & 10 & -15 & -5 \\
$\begin{array}{l}\text { Proses Bisnis Internal } \\
\begin{array}{l}\text { Pembelajaran } \\
\text { Pertumbuhan }\end{array}\end{array}$ & -10 & 14 & 14 & -6 & -10 \\
$\begin{array}{l}\text { Total Skor } \\
\text { Kesimpulan Kinerja }\end{array}$ & -5 & -10 & -10 & -10 & -10 \\
& 10 & -5 & 7 & -5 & -5 \\
& kurang & kurang & kurang & kurang & kurang \\
\hline
\end{tabular}

Pada Tabel di atas diperoleh skor kinerja PDAM di Provinsi Jambi berdasarkan balanced scorecard yang memperlihatkan secara keseluruhan kinerja PDAM masih dikategorikan kurang dari target kinerja maksimal. Meskipun begitu PDAM Tirta Mayang menunjukkan skor nilai paling tinggi yaitu 21. Hal ini dikarenakan PDAM Tirta Mayang secara finansial telah didukung oleh jumlah pelanggan yang cukup banyak. Selain itu perkembangan Kota Jambi yang cukup pesat mendukung semakin diperlukannya air bersih untuk pemukiman dan usaha. Nilai kinerja yang paling rendah diperoleh oleh PDAM Tirta Pangabuan yaitu sebesar -36. Kondisi geografis Kabupaten Tanjung Jabung Barat dan jumlah penduduk yang relatif sedikit turut mempengaruhi kinerja PDAM ini. Kondisi geografi yang sebagian besar terdiri dari rawa mempengaruhi besarnya investasi dan biaya yang dikeluarkan untuk memenuhi kebutuhan masyarakat terhadap air bersih. Kepadatan penduduk yang tidak banyak dan tidak berimbang juga mempengaruhi cakupan pelayanan terhadap pelanggan.

Hubungan Good Corporate Governance dan Kinerja PDAM yang diukur berdasarkan Balanced Scorecard. Hubungan antara praktik good corporate governance (GCG) terhadap kinerja PDAM berdasarkan balanced scorecard(BSC) diuji menggunakan 
korelasi Product Moment. Uji korelasi menggunakan Product Moment menunjukkan nilai korelasi 0,867 pada nilai $p$-value 0,057 . Nilai korelasi 0,867 menunjukkan korelasi praktik GCG memiliki hubungan yang kuat. Uji korelasi memiliki nilai $p$-value lebih besar dari alpha 0,05 sehingga hasil ini juga memiliki arti praktik good corporate governance memiliki hubungan korelasi terhadap kinerja PDAM namun tidak signifikan, dengan kata lain hipotesis alternatif yang diajukan tidak dapat didukung. Hasil ini juga tidak sejalan dengan penelitian sebelumnya (Mitton, 2002; Klapper dan Love, 2002; Darmawati, 2005; Wardhani, 2008; Nuswandari, 2009; Haryani, dkk., 2011) yang menunjukkan terdapat hubungan dan pengaruh good corporate governance terhadap kinerja perusahaan. Perbedaan indeks yang digunakan dalam good corporate governance (GCG) antara penelitian sebelumnya dengan penelitian ini dapat menjadi penyebab perbedaan hasil penelitian. Begitupun ukuran kinerja perusahaan, penelitian sebelumnya menggunakan ukuran kinerja keuangan sedangkan penelitian ini kinerja diukur dengan balanced scorecard.

\section{PENUTUP}

Simpulan. Analisis data diperoleh simpulan bahwa praktik good corporate governance (GCG) terhadap kinerja PDAM memiliki hubungan korelasi yang kuat namun tidak signifikan. Temuan ini berbeda dengan hasil penelitian sebelumnya yang dapat disebabkan adanya perbedaan indeks GCG dalam mengukur praktik good corporate governance dan ukuran kinerja perusahan.

Pelaksanaan praktik good corporate governance pada PDAM Tirta Mayang Kota Jambi, PDAM Tirta Muaro Jambi Kabupaten Muaro Jambi, dan PDAM Tirta Batanghari Kabupaten Batanghari pada rentang bobot skor 60-75 dalam kriteria cukup baik. Hasil ini menunjukkan bahwa PDAM belum sepenuhnya mempraktikkan good corporate governance berdasarkan Peraturan Menteri BUMN Nomor Per-01.MBU/2011 tentang penerapan tata kelola perusahaan yang baik (good corporate governance) pada badan usaha milik Negara.

Skor kinerja PDAM di Provinsi Jambi yang diukur menggunakan balanced scorecard memperlihatkan secara keseluruhan kinerja PDAM masih dikategorikan kurang dari target kinerja maksimal. Meskipun begitu PDAM Tirta Mayang menunjukkan skor nilai paling tinggi. Hal ini dikarenakan PDAM Tirta Mayang secara finansial telah didukung oleh jumlah pelanggan yang cukup banyak. Selain itu perkembangan Kota Jambi yang cukup pesat mendukung semakin diperlukannya air bersih untuk pemukiman dan usaha. Nilai kinerja yang paling rendah diperoleh oleh PDAM Tirta Pangabuan. Kondisi geografis Kabupaten Tanjung Jabung Barat dan jumlah penduduk yang relatif sedikit turut mempengaruhi kinerja PDAM ini. Kondisi geografi yang sebagian besar terdiri dari rawa mempengaruhi besarnya investasi dan biaya yang dikeluarkan untuk memenuhi kebutuhan masyarakat terhadap air bersih. Kepadatan penduduk yang tidak banyak dan tidak berimbang juga mempengaruhi cakupan pelayanan terhadap pelanggan.

\section{DAFTAR PUSTAKA}

Cahyono, Dwi, (2000) "Pengukuran Kinerja Balanced Scorecard untuk organisasi sektor publik", Jurnal Bisnis dan Akuntansi, 2 (3), Edisi Desember. 
Darmawati, Deni, Khomsiyah, dan Rika Gelar Rahayu, (2005) "Hubungan Corporate Governance dan Kinerja Perusahaan”, Jurnal Riset Akuntansi Indonesia, 8 (1), Edisi Januari.

Haryani, Linggar Pratiwi, dan Muchamad Syafruddin, (2011) Pengaruh Mekanisme Corporate Governance terhadap Kinerja: Transparansi sebagai Variabel Intervening, Dipresentasikan pada Simposium Nasional Akuntansi XIV Aceh.

Helfert, Erich.A, (1996) Teknis Analisis Keuangan (Petunjuk Praktis untuk Mengelola dan Mengukur Kinerja Perusahaan), Erlangga, Jakarta.

Jensen, M.C. and W.H. Meckling, (1976) "Theory of the Firm: Managerial Behavior, Agency Cost and Ownership Structure”, Journal of Financial Economics 3 (4): 305360.

Kaplan, Robert S., dan David P. Norton, (2000) Balanced Scorecard, Erlangga, Jakarta.

Klapper, Leora F., and I. Love, (2002) Corporate Governance, Investor Protection, and Performance in Emerging Markets. World Bank Working Paper, http://ssrn.com, diakses tanggal 20 Februari 2013.

Mahmudi, (2007) Manajemen Kinerja Sektor Publik, UPP STIM YKPN, Yogyakarta.

Mahsun, Mohamad, (2009) Pengukuran Kinerja Sektor Publik, BPFE, Yogyakarta

Mitton, T, (2002) A Cross-firm Analysis of The Impact of Corporate Governance on the Easr Asian Financial Crisis, Journal of Financial Economics, 64 (2): 215-241

Mulyadi, (2001) "Balanced Scorecard: Alat Manajemen Kontemporer untuk Pelipatganda Kinerja Keuangan Perusahaan, Salemba Empat, Jakarta.

Mulyadi, (2007) Sistem Terpadu Pengelolaan Kinerja Personel berbasis Balanced Scorecard, UPP STIM YKPN, Yogyakarta.

Nuswandari, Cahyani, (2009) "Pengaruh CGPI terhadap Kinerja Perusahaan pada Perusahaan yang Terdaftar di Bursa Efek Jakarta”, Jurnal Bisnis dan Ekonomi, 16 (2), Edisi September.

Prayogi, Bendo, (2011) "Analisis Kinerja PDAM Kota Samarinda dengan Pendekatan Balanced Scorecard", Tesis, Universitas Indonesia.

Rangkuti, Freddy, (2014) SWOT Balanced Scorecard, Gramedia Pustaka Utama, Jakarta. Wardhani, Ratna, (2006) Mekanisme Corporate Governance dalam Perusahaan yang Mengalami Permasalahan Keuangan, Dipresentasikan pada Simposium Nasional Akuntansi IX Padang. 